\title{
锞 先端材料としてのガラス
}

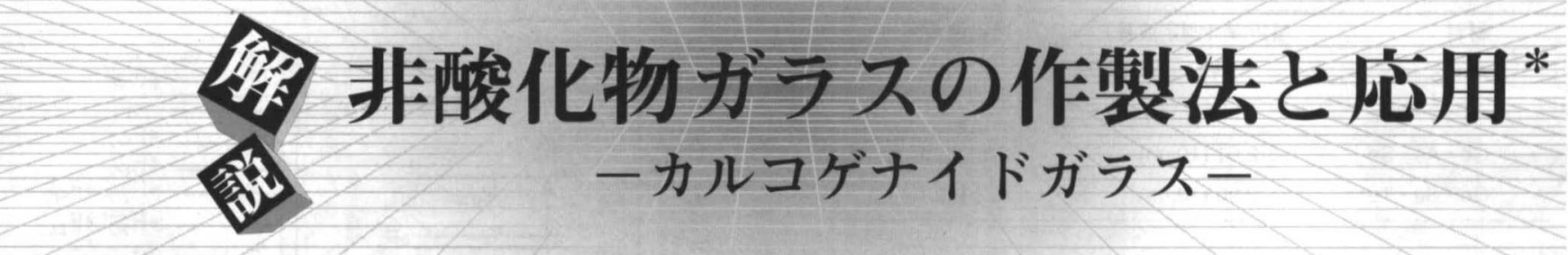

\section{浅原慶之 **}

Fabrication Process and Applications of Non-Oxide Glasses - Chalcogenide Glasses - / Yoshiyuki Asahara Key words: chalcogenide glass, fabrication process, IR-transmitting fiber, nonlinear optics, optical amplifier

\section{1.はじめに}

カルコゲナイドガラスは, カルコゲン (親銅) 元素と総称 される VI 族元素の S, Se, Te と, V 族元素の As, Sb，あ るいは，IV 族元素の Ge などの組み合わせを基本的なガラ ス形成化合物とするガラスである. S および Se は，らせ ん状の鎖構造を有し,これらが絡み合って粘性を增加させ， 単独でガラス化する。ささらに, As や Ge は，鎖構造を架橋 して網目を強化する役割をする ${ }^{1)}$.

このガラスは, 酸化物ガラスと比べて種々の特異な性質 を持つ. 酸化物ガラスがイオン電導性であるのに対して, カルコゲナイドガラスは正孔や電子などの素電荷が電導の 担体となるいわゆる電子電導性である。しかも，一部の組 成で電気的なスイッチ現象やメモリ一現象が報じられ，固 体物理の立場からそのバンド構造や電子構造の基礎理論が 研究された。電気的には, その後, 電子写真用感光膜や撮 像管用光電導膜として利用された ${ }^{2}$.

光学的には,このガラスは $8-14 \mu \mathrm{m}$ 波長帯の光を透過 するレンズ材料や赤外透過材料として昔から良く知られた 材料である ${ }^{1)}$.3). ごく最近では，この赤外透過性を活かし た赤外ファイバ材料として，また，高速光スイッチ用の光 非線形ファイバ材料, あるいは, 希土類ドープ光増幅ファ イバ用のホスト材料として注目されている.この他, 光照 射によって吸収端や屈折率の永続的変化を起こすいわゆる

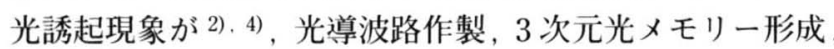
ガラスの微細加工などに ${ }^{5)}$, また, 光照射による結晶・ガ ラス間の相転移現象が，書き換え可能な光ディスクや DVD 用の記録薄膜材料として利用されている ${ }^{6)}$. 本稿で

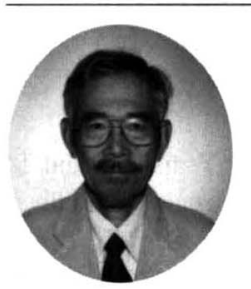

* 原稿受付 平成 16 年 1 月 1 日

**フォトニクス技術コンサルタント（東京都西多 摩郡瑞穗町むさし野 2-43-35)

浅原慶之

1964 年, 東京都立大学理学部物理学科卒. 工学 博士。～ 1996 年. HOYA（株）材料研究所。 1998 年九州大学客員教授、2000、2002 年東京 工業大学非常勤講師、現在フォトニクス技術コ ンサルタント

著書：Glasses for Photonics(CUP)，他に分担執 筆 14 編.
は, この様な多用な用途を持つカルコゲナイドガラスのう ちから，特にファイバ材料として利用される場合を取り上 げ，その作製法と応用例を紹介する事にする.

\section{2. 作 製 法}

\section{1 ガラスの製造方法 7), 8}

光ファイバ材料の基本的な特性である透過特性は, 短波 長側の電子遷移吸収や長波長側の赤外フォノン吸収に加え て, 外的な要因である不純物吸収, 微結晶による散乱に依 存する．特に成分の酸化不純物は吸収や損失の原因となる ので, 原料と溶融工程の管理が重要である。このため, 純 度が 6-7 Nの市販原料を, カルコゲン元素の場合は蒸留, As の場合は昇華, Ge の場合は水素ガス処理精製して使用 する. As や $\mathrm{Ge}$ の酸化不純物は, 原料精製の際に酸素親和 性の高い $\mathrm{Al}$ や $\mathrm{Mg}$ を微量に添加し，酸素をトラップする ことによって減らすことが出来る。

ファイバの透過スペクトルには，微量に含まれる不純物 の $\mathrm{O}-\mathrm{H}, \mathrm{Se}-\mathrm{H}$, あるいは, $\mathrm{Se}-\mathrm{H}$ 伸縮振動に起因して, $3 \mu \mathrm{m}, 4.1 \mu \mathrm{m}$ ，及び $4.6 \mu \mathrm{m}$ に大きな吸収が観測される。 こ の吸収は, $\mathrm{S}$ や $\mathrm{Se}$ を $\mathrm{Se}_{2} \mathrm{Cl}_{2}$ ガス雲囲気中で蒸留すること によって減らすことができる。

精製した原料は，アルゴンを満たしたグローブボックス 中で秤量する。これを $1.3 \times 10^{-5} \mathrm{~Pa}$ の真空中で石英ガラス アンプル中に封入し，摇籃炉で摇らしながら加熱溶融して ガラスの均質化を促進する。ロッドインチューブ法で使用 するコア用ロッドは，冷却過程でアンプルを垂直にして回 転させて作製する．クラッド用のチューブは，アンプルを 水平に保ちながら回転することで，アンプルの周囲にガラ スが片寄ることを利用して作製する。

\section{2 ファイバ作製法 7), 8)}

カルコゲナイドガラスファイバは、酸化防止用のテフロ ンを直接被覆しながら，ガラスクラッドなしでコア用のロ ッドや坩堝から紡系することもあるが，この場合，テフロ ンの強い固有吸収が $7.5 \mu \mathrm{m}$ と $11 \mu \mathrm{m}$ に現れ，ファイバの透 過波長帯は $7.5 \mu \mathrm{m}$ 以下の波長域に限られる。 
表 1 各種カルコゲナイドガラスファイバーの屈折率と透過波長帯

\begin{tabular}{lcc}
\hline 材料 & 屈折率〔測定波長〕 & 透過波長带 \\
\hline As-S & $2.41(5 \mu \mathrm{m})$ & $1-7 \mu \mathrm{m}$ \\
As-S-Se & $2.44(5 \mu \mathrm{m})$ & \\
$\mathrm{Ge}-\mathrm{As}-\mathrm{Se}$ & $2.61(10 \mu \mathrm{m})$ & $3-9 \mu \mathrm{m}$ \\
$\mathrm{Ge}-\mathrm{Se}-\mathrm{Te}$ & $2.90(10 \mu \mathrm{m})$ & $5-12 \mu \mathrm{m}$ \\
\hline
\end{tabular}

コアとクラッドからなるファイバの作製法には，ロッド インチューブ法や二重坩堝法があるが, カルコゲナイドガ ラスの場合, これらの方法ではコア・クラッド界面での融 着不良や微結晶生成が起こり，透過損失の原因となる。そ こで，両者を組み合わせた特殊な方法が採られる。

コアロッドとクラッドチューブは $130{ }^{\circ} \mathrm{C} て ゙$ 真空乾燥し 組み合わせて不活性ガスが満たされた石英管の中に挿入す る。コア・クラッド界面の密着性を改善するために，管の 中では，ロッドとチューブの隙間は $1.3 \mathrm{~Pa}$ に減圧し，外側 からはアルゴンガスで $2 \times 10^{5} \mathrm{~Pa}$ の圧力をかける。ファイ バノズルの近傍はアルゴン雲囲気にして，局部的に加熱す ると同時に，紫外線硬化アクリル樹脂で外側を被覆しなが

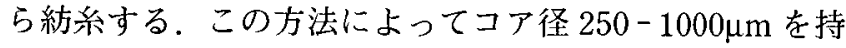
つファイバの作製が可能となる.

\section{3. カルコゲナイドガラスファイバの応用}

材料の赤外透過波長限界は，不純物吸収を除けば，構成 する化合物のフォノン吸収に依存する。酸化物ガラスの場 合, ガラス形成酸化物のフォノン吸収 (B-O: $1400 \mathrm{~cm}^{-1}, \mathrm{Si}$ $\left.\mathrm{O}: 1100 \mathrm{~cm}^{-1}, \mathrm{P}-\mathrm{O}: 1200 \mathrm{~cm}^{-1}\right) に よ っ て$ 赤外透過波長限界は 制限される(石英ガラス：0.16-4 コゲナイドガラスの多くは，各構成元素間は弱い不規則等 洒結合から成り，そのフォノンエネルギーは低く(250$\left.500 \mathrm{~cm}^{-1}\right)$ ，弗化物ガラスよりさらに長波長まで透過する能 力を有する(表 1).このため，レーザ加工機やレーザメス に使われる一酸化炭素レーザー $(5.2-5.4 \mu \mathrm{m})$ や炭酸ガスレ 一ザ $(10.6 \mu \mathrm{m})$ を伝送するファイバとして有用である $\left.{ }^{8)}, 9\right)$. 組成としては，透過波長域の関係から $5 \mu \mathrm{m}$ 帯には As - S

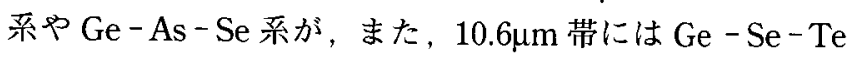
系が使用される。

高速光情報処理用の光スイッチ材料として，力ルコゲナ イドガラスの高い 3 次光非線形性(光照射による屈折率の 瞬間的な変化)を利用する試みがある 10$) ， 11) . \mathrm{As}_{2} \mathrm{~S}_{3}$ ファイ バの場合, 非線形屈折率(屈折率の変化の程度を表す係数) は $2-4 \times 10^{-14} \mathrm{~cm}^{2} / \mathrm{W}$ であり，吕英ファイバの $2.7 \times 10^{-16}$ $\mathrm{cm}^{2} / \mathrm{W}$ と比べると 2 桁以上大きく，低パワーで高速のス イッチを実現する可能性がある。

広带域の光通信波長带の一つである $1.3 \mu \mathrm{m}$ 帯に増幅波 長域を有する $\mathrm{Pr}^{3+}$ や $\mathrm{Dy}^{3+}$ を含有する光ファイバのホスト ガラスとして，低フォノンのカルコゲナイドガラスが注目 される ${ }^{10) ， 12)}$. $\operatorname{Pr}^{3+}$ イオンの場合, $1.3 \mu \mathrm{m}$ の信号光の増幅 には ${ }^{1} \mathrm{G}_{4}-{ }^{3} \mathrm{H}_{5}$ の誘導放出遷移を利用するが (図 1 参照)，

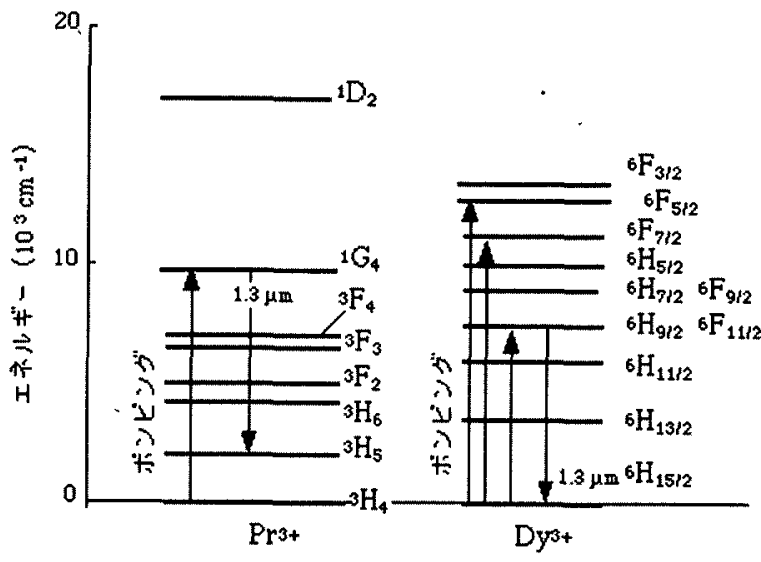

图 $1 \mathrm{Pr}^{3+}$ および $\mathrm{Dy}^{3+}$ イオンのエネルギー準位と， ポンピングおよび増幅プロセス

${ }^{1} \mathrm{G}_{4}$ の直下にある ${ }^{3} \mathrm{~F}_{4}$ とのエネルギー差が $3000 \mathrm{~cm}^{-1}$ と小さ いために,フォノンエネルギーの大きい石英ガラスの場合， ${ }^{1} \mathrm{G}_{4}$ 準位に励起された $\operatorname{Pr}^{3+}$ イオンは多フォノン緩和を介し て容易に ${ }^{3} \mathrm{~F}_{4}$ に非輻射遷移し，誘導放出は殆じ起こらない。 この事情は，ディスプロシウムの場合も同様である（図 1 参照). 一方, カルコゲナイドガラスの場合, 多フォノン 緩和は起こり難く効率の良い増幅が可能となる。たた，ガ ラスとして安定な $\mathrm{As}-\mathrm{S}$ 系, あるいは， $\mathrm{Ge}-\mathrm{S}$ 系ガラスは 共有結合性が強く, 希土類イオンの高濃度の溶解は難しい. このため，イオン性の高い $\mathrm{Ga}$ や Inなどの陽イオンや $\mathrm{PrCl}_{3}$ を添加したり，希土類硫化物と組み合わせて，10 $\mathrm{mol} \%$ 以上の高濃度の希土類イオンを溶解する工夫がなさ 机る ${ }^{13)}$.

\section{4. あとがき}

以上, 主にカルコゲナイドガラスファイバ作成法と応用 例に関して解説した。ささらに細かな情報を望まれる方の為 に，参考文献には二次情報を記載した。興味のある万はこ れを元に一次情報を検索されたい.

\section{参 考 文 献}

1）土橋正二: 泉谷徹郎監修, 新しいガラスとその物性, 経営システム 研究所, (1984) 407.

2）渡辺裕一: ニューガラスハンドブック,ニューガラスハンドブック 編集委員会糄, 丸善株式会社, (1991)124.

3）浅原慶之, 泉谷徹郎:「アモルファス電子材料利用技術集成」桜井 良文, 浜川圭弘監修,サイエンスフォーラム, (1981) 511.

4）田中啓司: カルコゲナイドガラス概観，セラミックス, 36, 12 (2001) 80

5）三浦清貫: フェムト秒レーザーによるガラスへの光導波路描画，七 ラミックス, 36, 12 (2001) 67 .

6）太田威夫: 相変化メモリーの DVD 光ディスクへの展開, セラミッ クス, 36, 12 (2001) 92.

7）山岸隆司:ニューガラスハンドブック,ニューガラスハンドブック 編集委員会編, 丸善株式会社, (1991) 267.

8) J. Nishii, S. Morimoto, I. Inagawa, R. Iizuka, T. Yamashita and T Yamagishi: Recent advances and trends in chalcogenide glass fiber technology: a review, J. Non-cryst. Solids 140 (1992) 199.

9）山下俊晴: 赤外ファイバー開発の最前線,レーザー研究, 27, 13 (1999) 167.

10）遊部雅生, 金森照寿: カルコゲナイドガラスファイバーの能動的光 
デバイスへの応用, 応用物理, 69, 7, (2000) 797.

11) M. Yamane and Y. Asahara: Glasses for Photonics, Cambridge University Press, Cambridge, (2000) 159.

12) M. Yamane and Y. Asahara: ibid, 106.

13）武部博倫, 森永健次: 希土類イオンドープカルコゲナイドガラスの 組成とその光学特性, セラミックス, 36, 12 (2001) 84 . 